\title{
PENINGKATAN PERAN KONSELOR DI BIDANG KESEHATAN PADA PUSAT INFORMASI KONSELING GIBITA DAN KARANG TARUNA LINGGASARI
}

\author{
Atyanti Isworo'), Endang Triyanto ${ }^{2)}$, Wahyu Ekowati ${ }^{3)}$ \\ 1,2,3 Jurusan Keperawatan, Fakultas Ilmu-Ilmu Kesehatan, \\ Universitas Jenderal Soedirman \\ E-mail: atyanti.isworo@gmail.com
}

\begin{abstract}
The number of adolescents in the Purwokerto area is the third highest in the Central Java Province. Adolescence is very closely related to the puberty period which is accompanied by sexual development. This condition makes adolescents are prone to various forms of behavioral problems, such as having sex before marriage and drug abuse, both of which can carry risks to HIV / AIDS transmission. It is very important to instill good morale in the younger generation through youth organizations, such as youth organizations and counseling information centers. However, teenage health problems were found, especially in the area of Linggasari Youth Center and the "Gibita" Information Counseling Center/ Pusat Informasi Konseling (PIK) such as lack of understanding of HIV / AIDS, the dangers of smoking, and adolescent reproductive health. To overcome this problem, we trained Adolescent Counselors. Classroom learning, problem based solving, participatory learning, role play were used in this project. The result revealed that this activity enhances the understanding of knowledge and skills of new counselors on adolescent health problems. In addition, we also produced modules and film (roleplay and educational videos) of adolescent health problems counseling.
\end{abstract}

Keywords: Counselor; Health; Adolescent; Youth Organization; Information Counseling Center

\section{PENDAHULUAN}

Jumlah remaja di daerah Purwokerto merupakan ketiga terbanyak di Propinsi Jawa Tengah. Purwokerto merupakan kota yang memiliki kelompok remaja yang tercatat per April tahun 2009 sekitar 34\% dari total penduduk atau 1.802 .152 jiwa (Dinas Kependudukan dan Pencatatan Sipil
Banyumas, 2009). Berdasarkan data tersebut dapat disimpulkan bahwa proporsi remaja di Purwokerto adalah sekitar satu pertiga dari jumlah keseluruhan. Sebaran remaja di Purwokerto terbanyak di Baturaden, Bobosan, Mersi, Arca dan Linggasari (Dinas Kependudukan dan Pencatatan Sipil Banyumas, 2009).

12 Peningkatan Peran Konselor di Bidang Kesehatan... 
Kepedulian pemerintah terhadap masalah kesehatan remaja cenderung semakin tinggi, terutama masalah kesehatan reproduksi. Hal ini disebabkan antara lain karena berbagai masalah yang dihadapi remaja semakin kompleks. Masa remaja sangat erat kaitannya dengan periode pubertas yang diiringi dengan perkembangan seksual. Kondisi ini menyebabkan remaja menjadi rentan terhadap masalah-masalah perilaku berisiko, seperti melakukan hubungan seks sebelum menikah dan penyalahgunaan napza, yang keduanya dapat membawa risiko terhadap penularan HIV/AIDS.

Hal inilah yang menyebabkan penting sekali untuk menanamkan moral yang baik pada generasi muda, salahsatunya melalui organisasi kepemudaan, seperti karang taruna dan pusat informasi konseling.

Karang taruna Linggasari keberadaannya sudah cukup lama. Namun saat ini kegiatan tentang konseling kesehatan yang dulu dilakukan oleh konselor sebaya mengalami penurunan, dikarenakan kesibukan konselor tersebut. Sedangkan pengurus baru belum mendapatkan pelatihan konselor. Padahal masalah kesehatan di Linggasari lumayan kompleks. Berdasarkan pengkajian didapatkan hasil sebagian besar remaja belum memahami HIV/AIDS dan bahaya merokok, kurang memahami kesehatan reproduksi remaja. Terdapat pula remaja yang merokok dan minuman alkohol. Pengurus karang taruna ini mengharapkan bantuan untuk pelatihan bagi konselor sehingga konselor dapat memerankan tugasnya di wilayah ini.

Sedangkan Pusat Informasi Konseling (PIK) Gibita yang berada di wilayah Rempoah Baturaden telah mempunyai banyak kiprah di bidang kesejahteraan masyarakat. Namun saat ini, PIK Gibita juga mengalami masalah yang sama seperti karang taruna Linggasari. Para konselor baru belum mendapat pelatihan yang baik dan terstruktur tentang masalah remaja. Padahal daerah Rempoah Baturaden ini terdapat lokalisasi yang berpotensi tinggi terjadinya HIV/AIDS. Data dari Dinas Kesehatan Kabupaten Banyumas menunjukkan terjadi kecenderungan peningkatan pengidap AIDS di Banyumas untuk remaja usia 15-24 tahun. Data terbaru menunjukkan angka kejadian pengidap AIDS pada golongan usia tersebut mencapai $18 \%$ (Dinkes Banyumas, 2012).

Terkait dengan cita-cita bangsa Indonesia menjadi bangsa yang berkarakter terutama generasi muda "untuk meningkatkan pengetahuan, sikap dan perilaku hidup sehat dan berakhlaq demi terwujudnya generasi berencana" maka untuk menuju 
GEMASSIKA: Jurnal Pengabdian Kepada Masyarakat

Vol. 4 No. 1 Mei 2020

cita-cita tersebut para pengabdi dari Jurusan Keperawatan Unsoed melakukan solusi Pelatihan Konselor Remaja dan Masalah Kesehatan Remaja. Tujuan pelatihan konselor remaja ini adalah untuk (1) Meningkatkan peran organisasi remaja seperti Karang Taruna dan PIK (Pusat Informasi dan Konseling) dalam proses konseling kesehatan

Meningkatkan kemampuan dan keterampilan para konselor kesehatan remaja pada Karang Taruna Linggasari dan Pusat Informasi Konseling (PIK) Gibita.

\section{MASALAH, TARGET DAN LUARAN}

Masalah yang dihadapi oleh Karang taruna Linggasari maupun Pusat Informasi Konseling gibita adalah hampir sama yaitu:

1. Kegiatan karang taruna dan PIK Gibita belum berjalan secara optimal karena kurangnya pengetahuan tentang tata kelola organisasi dan belum ada kegiatan tentang peningkatan pengetahuan terkait kesehatan reproduksi remaja.

Solusi yang ditawarkan adalah pendampingan tentang tata kelola organisasi

2. Remaja di lingkungan karang taruna Linggsari banyak yang merokok, ada yang minum minuman keras, menjalani pernikahan dini. Kondisi ini juga dialami oleh remaja di PIK Gibita. Solusi yang ditawarkan adalah pelatihan konselor peer group tentang kesehatan reproduksi remaja. Konselor berasal dari remaja di lingkup karang taruna Linggasari dan PIK Gibita. Langkahnya:

- Memilih calon konselor yang memiliki kemampuan komunikasi yang baik

- Melakukan pelatihan konselor

- Membuat media tentang kesehatan reproduksi remaja, baik yang berupa buku ataupun audiovisual

- Membuat perenacaan kegiatan yang terjadwal tentang kesehatan reproduksi remaja

- Pendampingan saat pelaksanaan konseling

Luaran utama dari kegiatan pengabdian ini adalah produk yang berupa modul bagi konselor yang berisi tentang konsep konselor, pendekatan dan komunikasi pada remaja, masalah kesehatan remaja serta modul dan video tentang berbagai masalah kesehatan remaja. Berikut adalah contoh cover modul dan video yang menjadi luaran dalam kegiatan ini: 


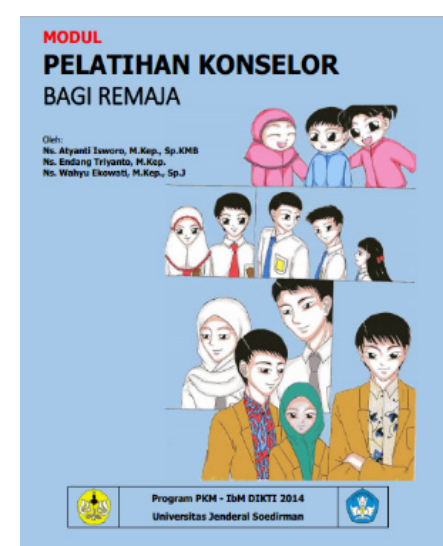

Gambar 1. Cover modul pelatihan konselor
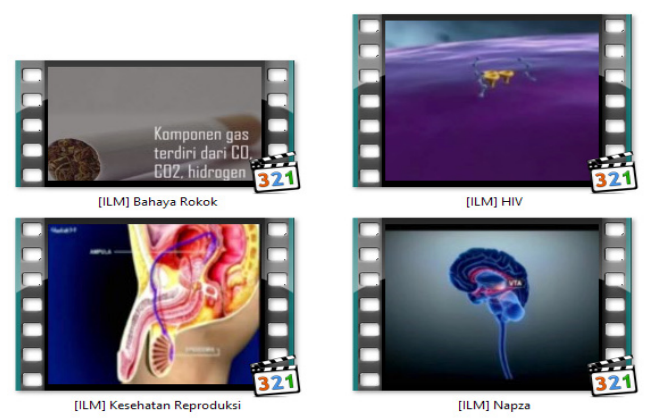

Gambar 2. Capture video konseling
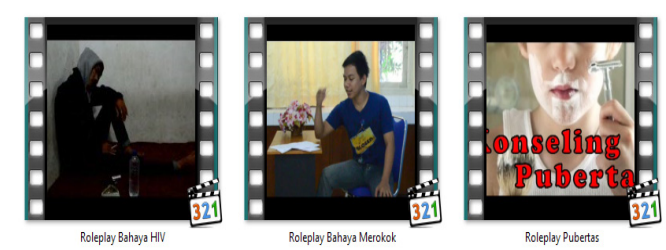

Gambar 3. Capture video roleplay

\section{METODE PELAKSANAAN}

Kegiatan yang dilakukan pada program pengabdian IbM ini adalah sebagai berikut:
a. Pelatihan Konselor
b. Pelatihan Kesehatan Reproduksi Remaja
c. Pelatihan tentang HIV/AIDS
d. Pelatihan tentang Bahaya Rokok

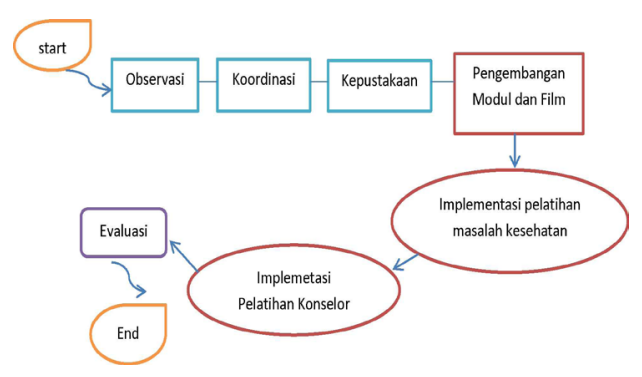

Skema alur metode yang dilakukan

Sedangkan metode dan prosedur IbM yang dilakukan pada pelatihan konselor ini adalah:

\section{a. Koordinasi}

Untuk mendapatkan data-data yang dibutuhkan dalam pelatihan konselor, perlu dilakukan hal-hal berikut:

1) Observasi

Pengamatan dan pengumpulan data dilakukan terhadap kinerja pengurus terutama yang membawahi bidang kesehatan baik pada mitra Karang Taruna Linggasari dan mitra PIK Gibita

2) Wawancara

Wawancara langsung kepada para pengurus untuk mendapatkan peserta pelatihan konselor dan memperoleh masukan terhadap metode yang digunakan 


\section{3) Kepustakaan}

Mencari literatur tentang konselor, remaja dan masalah kesehatan remaja untuk kemudian dikembangkan dalam bentuk modul-modul pelatihan.

b. Pengembangan Modul dan media Film Pada tahap ini dikembangkan modulmodul dan film yang dibutuhkan dalam pelaksanaan program IbM ini.

c. Implementasi pelatihan tata kelola organisasi dan masalah kesehatan reproduksi remaja

Kegiatan ini dilakukan secara berkelanjutan dengan metode klasikal dan participatory learning.

\section{d. Implementasi pelatihan konselor}

Pada tahap ini dilakukan penerapan pelatihan konselor dengan metode klasikal, participatory learning, diskusi dalam problem based solving, role play.

\section{e. Evaluasi}

Evaluasi kegiatan dapat dilakukan dengan mendapatkan masukan tentang pelatihan yang telah diberikan kepada calon konselor (pengurus karang taruna dan PIK maupun remaja yang terlibat dalam pelatihan ini).

\section{HASIL PEMBAHASAN}

Hasil yang telah dicapai dari berbagai kegiatan yang telah dilakukan pada program pengabdian ini adalah peningkatan pengetahuan tentang tata kelola organisasi. Karang taruna merupakan organisasi kepemudaan dengan tujuan untuk mencegah, mengatasi masalah kesejahteraan sosial; pengembangan usaha kemandirian; peningkatan potensi generasi muda yang terarah dan kesinambungan. Oleh karena tujuan yang sangat penting tersebut, setiap pengurus ataupun yang terlibat dalam organisasi ini perlu memahami pengelolaan organisasi. Dengan pemahaman yang baik maka organisasi ini akan berjalan dengan baik pula. Di sini para peserta menyampaikan memahami peran, tanggung jawab, program kerja dan membenahi atau membentuk kembali AD/ART organisasi. Dengan pemahaman ini maka organisasi Karang Taruna dan PIK Gibita akan berperan dalam proses konseling kesehatan.

Selain menghasilkan peningkatan pemahaman tentang tata kelola organisasi , dalam kegiatan ini juga terbentuk "konselor kesehatan reproduksi bagi remaja". Berikut adalah gambar konselor yang baru terbentuk. 


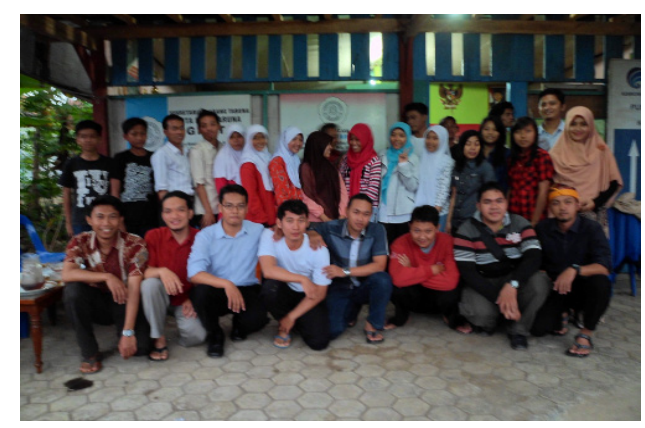

Gambar 4: konselor baru dan tim pengabdi

Pada masa remaja terjadi perubahan fisik dan hormonal yang memicu masalah kesehatan reproduksi remaja. Masalah kesehatan reproduksi remaja seperti kehamilan yang tidak diinginkan, penyakit menular seksual, narkotika dan HIV/AIDS (Margaretha, 2012). Beberapa penelitian menyatakan bahwa pemahaman tentang kesehatan reproduksi di kalangan remaja masih kurang (Mahadeen, et al, 2012; Haberland, 2015). Khalaf et al melaporkan remaja terbatas dalam memanfaatkan layanan tentang kesehatan reproduksi dikarenakan ketidakadekuatan pengetahuan tentang kesehatan reproduksi.

Pelatihan konselor remaja berupaya untuk mencegah permasalahan-permasalahan yang dihadapi remaja kaitannya dengan kesehatan reproduksi.

Pembentukan konselor remaja baik di karangtaruna Linggasari maupun PIK Gibita dianggap sukses. Hal ini terlihat dari peningkatan tingkat pengetahuan dari para konselor.
Para konselor remaja tersebut memiliki berbagai ragam karakteristik tingkat pendidikan maupun jenis kelamin. Hal ini akan mempermudah proses konseling, karena ada keragaman karakteristik konselor sejalan dengan keragaman para remaja sebayanya. Berikut adalah tabel karakteristik para konselor remaja yang baru dilatih pada kegiatan ini

Tabel 1. Karakterisitik Peserta

\begin{tabular}{|l|c|c|}
\hline \multicolumn{1}{|c|}{ Variabel } & $\begin{array}{c}\text { Desa } \\
\text { Linggasari }\end{array}$ & $\begin{array}{c}\text { PIK } \\
\text { Gibita }\end{array}$ \\
\hline Tingkat pendidikan & & \\
SMP/sederajat & 2 & 3 \\
SMA/sederajat & 13 & 12 \\
\hline Jenis Kelamin & 8 & 6 \\
Laki-laki & 7 & 9 \\
Perempuan & 15 & 15 \\
\hline Jumlah & & \\
\hline
\end{tabular}

Secara singkat, karakteristik tingkat pengetahuan konselor sebelum dan setelah pelatihan terlihat pada grafik berikut ini.

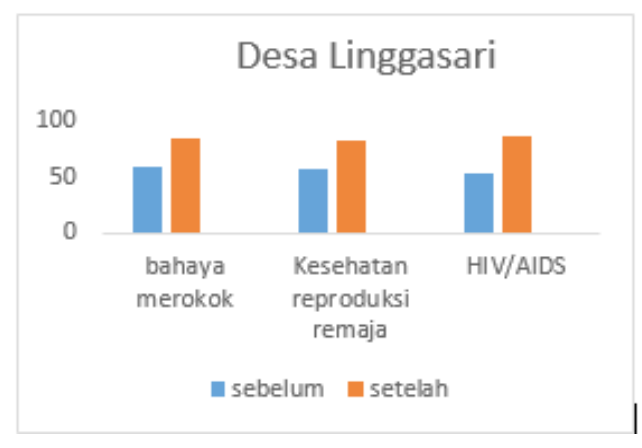

Gambar 4.

Tingkat Pengetahuan Calon Konselor Remaja di desa Linggasari 


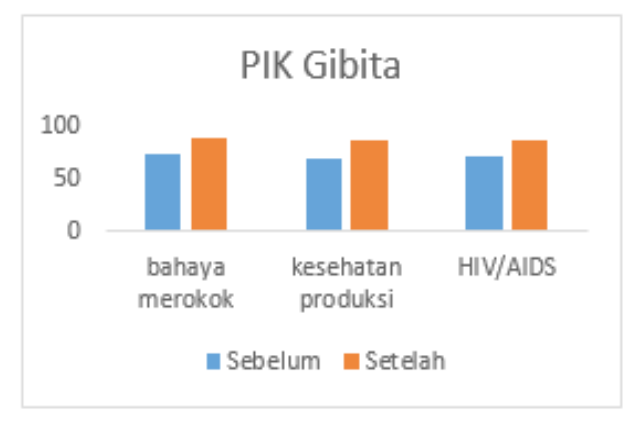

Gambar 5.

Tingkat pengetahuan calon konselor remaja di PIK Gibita

Metode yang dilakukan pada kegiatan ini adalah diskusi interaktif dua arah, role play dan praktik konseling. Media yang digunakan untuk kegiatan pengabdian ini juga bervariasi mulai dari power point, modul, lembar balik dan video.

Calon konselor diberikan pendidikan kesehatan sebagai bekal untuk menjadi konselor. Materi pendidikan kesehatan tersebut adalah kesehatan reproduksi, dasardasar menjadi konselor, teknik komunikasi dan sikap seorang konselor. Metode awal untuk pendidikan kesehatan ini adalah melalui diskusi interaktif. Diskusi interaktif mampu meningkatkan pengetahuan dan sikap tentang kesehatan reproduksi pada mahasiswa (Reem, 2018).

Role play juga diaplikasikan dalam kegiatan pelatihan ini. Dalam kegiatan ini, tim pengabdi melibatkan mahasiswa Jurusan Keperawatan Unsoed untuk memainkan peran sesuai skenario yang dibuat tim. Para calon konselor memperhatikan selanjutnya mereka diminta untuk redemonstrasi dengan sesama peserta dengan berbagai kasus skenario yang disediakan. dalam teknik role play ini, para konselor belajar untuk meningkatkan kemampuan berbicara. Beberapa studi menunjukkan manfaat role play dalam meningkatkan kemampuan berbicara dan mengurangi kecemasan saat berbicara. (Toyib \& Syafi'i, 2018; Sofyan, Buaja \& Rahman, 2018).

Selain itu, dalam kegiatan ini digunakan berbagai media pembelajaran. Secara umum manfaat media pembelajaran adalah memperjelas isi pesan yang disampaikan; mengatasi keterbatasan ruang, waktu tenaga, dan daya indera; meningkatkan motivasi belajar; memungkinkan peserta didik belajar secara mandiri sesuai bakat dan minat yang dimiliki; memberi rangsangan, pengalaman, dan rasa yang sama bagi setiap peserta didik. memiliki nilai praktis yakni mengatasi keterbatasan pengalaman yang dialami peserta didik (Wina, 2009 dalam Saifuddin, 2014). Media yang digunakan dalam kegiatan ini adalah video dan modul. Penggunaan media seperti modul dan video pembelajaran sangat membantu proses pelatihan bagi para calon konselor ini 
Video dapat meningkatkan hasil belajar kognitif karena merangsang beberapa jenis kecerdasan. Berdasarkan teori kecerdasan ganda yang dikemukakan oleh Gardner (2008), terdapat 8 jenis kecerdasan yakni kecerdasan linguistik, logika-matematika, musikal, kinestetik, visual spasial, interpersonal, intrapersonal, dan natural. Teori kecerdasan ganda menyarankan kepada pengajar untuk merangsang lebih dari satu jenis kecedasan tersebut untuk pengalaman belajar yang lebih baik. Pembelajaran dengan video dapat merangsang beberapa tipe kecerdasan sekaligus. Gambar dalam video dapat merangsang kecerdasan visual spaisal dan natural. Suara narasi dalam video dapat merangsang kecerdasan linguistik. Lebih lanjut video diketahui dapat memberikan gambaran yang lebih konkret terhadap materi yang disampaikan serta merangsang beberapa indra sekaligus seperti indra penglihatan dan indra pendengaran. Pembelajaran dengan video juga memberikan kepuasan dalam pengalaman belajar sehingga dapat meningkatkan minat pada peserta didik (Elsayed dan Elsayed, 2012).

Salah satu kutipan pendapat dari peserta adalah “... ku kira udah pas ya, ada yang dijelasin, pake video trus dipraktekkin. Hampir semua disuruh mencoba, prakteknya juga diulang-ulang. Jadi lebih ngerti caranya..”. Dengan demikian metode/ pendekatan yang dilakukan oleh tim pengabdi cukup efisien dan efektif dalam melatih calon konselor.

Selain video, media yang digunakan lainnya adalah modul. Modul memiliki pengaruh terhadap hasil belajar. Modul dapat memberikan petunjuk mengenai materi yang disampaikan secara instruksional dan jelas (Ikhtiarika, Panjaitan, dan Yokhebed, 2014). Lebih lanjut, fasilitas untuk implementasi program ini cukup memadai, baik di PIK Gibita maupun di Karangtaruna Desa Linggasari. Untuk PIK Gibita, telah memiliki ruang sekretariat, yang juga berfungsi sebagai taman bacaan dan ruang pertemuan. Sedangkan untuk para remaja di Desa Linggasari, telah dibentuk sekretariat untuk proses konseling remaja, yang bertempat di salah satu ruang di kompleks rumah milik Ibu Kepala Desa Linggasari.

Selain itu para calon konselor, juga telah mulai mempraktikkan ilmunya untuk menjadi konselor bagi teman-temannya. Mereka telah berupaya menyebarkan ilmu yang telah diperoleh sambil membantu memberi solusi terhadap masalah yang dihadapi oleh para teman-temannya. Meskipun di lapangan terdapat beberapa kendala, namun para calon konselor ini mampu mengatasinya. Berikut 
GEMASSIKA: Jurnal Pengabdian Kepada Masyarakat

Vol. 4 No. 1 Mei 2020

kutipan salah satu calon koselor terkait dengan upaya dan hambatan saat implementasi “..... ada teman yang cerita, bilang ada masalah. Awalnya saya bingung, tapi lalu saya coba alternatif berbagai solusinya... besokbesoknya dia tanya-tanya tentang haid dan pacaran. Jadi seneng bisa mbantu..."

Pendampingan untuk para konselor baru terus dilakukan baik melalui pertemuan langsung maupun luring, seperti menggunakan WhatsApp ataupun Facebook. Dari hasil yang telah dipaparkan, dapat disimpulkan bahwa kegiatan ini cukup berhasil dalam mendidik para calon konselor kesehatan remaja. Berbagai kegiatan yang telah dilakukan, modul pelatihan konselor, video pembelajaran, video roleplay, benar-benar membantu proses pembelajaran para calon konselor ini. Sebagai keberlanjutan kegiatan ini, secara berkala kami masih berkunjung ke sekretariat di masing-masing lokasi target (PIK Gibita dan remaja Linggasari) untuk memantau kegiatan, walau tempo kegiatan IbM ini telah selesai.

\section{KESIMPULAN DAN SARAN}

Kegiatan ini telah meningkatkan pemahaman dan keterampilan para konselor baru tentang masalah kesehatan remaja sehingga terbentuk konselor yang handal dan terampil. Bahkan kegiatan di PIK Gibita, juga menarik minat bagi PIK di desa sekitarnya untuk turut mengkader calon konselor kesehatan remaja. Selain itu juga telah dihasilkan produk berupa modul dan film (video pembelajaran dan video roleplay konselor) yang digunakan dalam kegiatan pengabdian ini.

Program yang dilaksanakan pada kegiatan ini baru sebatas pada pengkaderan konselor remaja. Ke depan, agar kegiatan ini dapat berkesinambungan, perlu dilakukan pelatihan secara kontinu sehingga kegiatan konseling remaja dapat berlanjut. Selain itu, kegiatan ini ternyata juga menarik minat bagi PIK di sekitar desa target, lebih lanjut, perlu dipertimbangkan untuk memperluas area kegiatan ini hingga ke PIK yang lain, khususnya di desa yang bertentangga dengan desa target pada kegiatan ini.

20 Peningkatan Peran Konselor di Bidang Kesehatan... 


\section{DAFTAR PUSTAKA}

Dinas Kependudukan dan Pencatatan Sipil Banyumas. (2009). Data Dinas Kependudukan dan Pencatatan Sipil Banyumas Tahun 2009. www.dindukcapil.banyumaskab.go.id

Dinas Kesehatan Kabupaten Banyumas. (2012). Profil Kesehatan Kabupaten Banyumas Tahun 2012. www.depkes.go.id

Gardner, H. I. (2008). Multiple intelligence: new horizone in theory and practice. Hacchete Publisher, United Kingdom : 107-113

Elsayed, R. E.H dan Elsayed, S. E. A. E., 2012, Video-based lectures: an emerging paradigm for teaching human anatomy and physiology to student nurses. Alexandria Journal of Medicine. 49 : 215-222.

Haberland NA. The case for addressing gender and power in sexuality and HIV education: a comprehensive review of evaluation studies. Int Perspect Sex Reprod Health. 2015;41(1):31-42

Hurlock, E. (2004). Psikologi perkembangan suatu pendekatan sepanjang rentang kehidupan.

Ed. Kelima. Yogyakarta: Erlangga

Khalaf I, Moghli FA, Froelicher ES. Youth-friendly reproductive health services in Jordan from the perspective of the youth: a descriptive qualitative study. Scand J Caring Sci. 2010;24(2):321-331

Mahadeen, A., Khalil, A., Hamdan-Mansour, A., Sato, T., Imoto, A. (2012). Knowledge, attitudes and practices towards family planning among women in the rural southern region of Jordan. East Mediterranian Health Journal. 18(6):567

Margaretha, L. (2012). Parenting practices and adolescent risk behavior: rules on smoking and drinking also predict Cannabis use and early sexual debut. Journal of Prev Sci.13:594604.

Reem, A.A. (2018). Effects on interactive teaching students' knowledge and attitude toward reproductive health. Journal of Multidisciplinary Healthcare, 11: 211-221.

Saifuddin, 2014, Pengelolaan pembelajaran teoritis dan praktis, Deepublish, Yogyakarta, 128145. 
GEMASSIKA: Jurnal Pengabdian Kepada Masyarakat

Vol. 4 No. 1 Mei 2020

Sofyan, N., Buaja, T., Rahman, O.R. (2018). The implementation of role play method in improving students' speaking skill: a classromm action research at grade IX students of SMP Muhammadiyah 1 Ternate. International journal of scientific \& technology research. 7 (12): 267-269.

Toyib, A.R., Syafi'i, A. (2018). Role-play as a method to overcome students's anxiety in speaking skill. Efektor. Vol 5 (1): 51-53

22 Peningkatan Peran Konselor di Bidang Kesehatan... 